\section{WATER STORAGE}

\section{Walls in the Wash}

THE next stage in the Water Resources Board's plan to obtain fresh water from the Wash was launched this week with the signing of a contract to build $£ 200,000$ worth of trial embankment in the estuary.

Sir Robert McAlpine and Sons is expected to sign the contract for the work during this week. The scheme is intended to produce 100 million gallons of water a day by the end of this century and between 500 and $600 \mathrm{mil}$ lion gallons a day eventually.

Work is scheduled to start next month to see if the seabed in the Wash will form a suitable foundation for the $8 \mathrm{~km}$ of wall that the first reservoir will require. The walls when completed will be about $14 \mathrm{~m}$ high and the trial embankment will have a crest $60 \mathrm{~m}$ long and a base length of $160 \mathrm{~m}$. The site chosen is at Breast Sand near King's Lynn.

The embankment is the beginning of a series of tests and construction trials that will cost $£ 1.6$ million over the next few years. This will eventually decide whether the walls will be able to withstand the tidal range encountered in the Wash, much larger than the range where estuary schemes have been built before. The tests will also help to determine the economics of the various methods of construction available.

\section{ENVIRONMENT}

\section{Will the Polluter Pay?}

"THE polluter must pay" is a political slogan and in practice the cost of keeping the environment clean must fall on the consumer, according to $\mathrm{Mr} \mathrm{A}$. I Biggs of the Confederation of British Industry. $\mathrm{Mr}$ Biggs was one of the contributors to a one day conference on industry and the environment, organized by The Engineer and held on Monday of this week.

Mr Biggs pointed out that this statement was at variance with policy on pollution problems in the United States. The Americans, said Mr Biggs, have opted for a pollution tax to force polluters to consider the environment, but in Britain most of the pollution comes from the general public-for example people who own motor carsand such a policy in Britain would not pay dividends. In particular it would be easier for any company in a monopoly position to pay the tax rather than cut down on pollution. The CBI, according to $\mathrm{Mr}$ Biggs, thinks "that pollution control should be considered as part of production costs".

$\mathrm{Mr}$ Biggs was not alone in making unfavourable comparisons of the way in which Britain and the United States are attacking pollution problems. $\mathrm{Mr}$ Peter Walker, Secretary of State for the Environment, delivered the opening address at the conference, and said that Britain would be spending $£ 850$ million in the next five years on sewerage plants but that Europe and the United States were lagging behind in this essential field. He also called for a pooling of research knowledge on pollution to avoid duplication and to achieve uniform standards.

Lord Byers, in his role as director of Rio Tinto Zinc, pointed out that the anti-trust laws in the United States were a barrier to the international pooling of knowledge, and he said that there was a need for the United States to look closer at its laws relating to antitrust matters. Dr Alan Mencher, Scientific Attaché at the United States Embassy, said that these laws were being considered at present and, although he did not give a detailed defence of the position of the United States on the various issues raised, he did point out that the audience would not be gathered together to discuss problems of the environment if the United States had not "developed a political awareness of pollution" and had not given the subject a great deal of publicity.

Sir Alan Cottrell, Chief Scientific Adviser to the government, expounded on the role of government science in the care of the environment. He mentioned several well known problemsfor example, DDT, and mercury in fish -and pointed out that research was needed to obtain reliable data with which the dangers could be properly evaluated. Research was necessary, said Sir Alan, to replace the guesswork evident in documents such as the Blueprint for Survival and The Limits to Growth.

$\mathrm{Mr}$ C. J. Moorehouse, representing Shell, expanded on Mr Walter's theme that it was essential that uniform stand. ards of pollution be set in all countries. In particular $\mathrm{Mr}$ Moorehouse was concerned at the prospect of countries setting independent standards for lead emission from cars. Mr Moorehouse said that the standards should be set by the OECD or the EEC. In another attack on legislation in the United States Mr Moorehouse said that the way in which pressure is being put on the automobile manufacturers and the oil industry to produce cars conforming to rigorous emission standards within a certain time is wrong. According to $\mathrm{Mr}$ Moorehouse there would be a fouryear delay in producing lead-free petrol if the British government asked for it, the final product would be more expensive than petrol including lead, and would also be less economical to use in a car. $\mathrm{Mr}$ Moorehouse added that the European countries "must not slavishly follow the United States's pattern" in setting emission regulations. He also pointed out that the "oil industry is in business to provide what society requires".

Mr L. Brook, chairman of Simon Engineering Ltd, approached reality when he said that what has to be decided is the "degree of pollution which is acceptable to life". $\mathrm{He}$ emphasized that if different countries set different standards then a tax credit system would have to be instituted to ensure that British companies are not at a disadvantage.

Although many of the participants professed that the conference had been informative and a great help to them, the basic question of whether or not the gross national product should continue to grow to the detriment of the environment was studiously avoided. But there was an overwhelming consensus among the industrialists that the cost of any improvements in processes that might be necessary to preserve the environment must be passed on to the public.

\section{STOCKHOLM CONFERENCE}

\section{Almost Ready to 60}

LAST week Mr Peter Walker, Secretary of State for the Environment, waved aloft the government's white glossy paper entitled The Human Environment : the British View and set the ball rolling for Stockholm. No doubt reams of newspaper comment and report are to follow, but the British government has kept its contributions reasonably compact.

The British View (HMSO, £1.20), in spite of a tendency to read like a party political broadcast, does give a careful and balanced picture of the environmental problems that Britain faces and is trying to solve. It casts its net fairly wide, including chapters on housing, local government, transport and architectural conservation, as well as the more obvious areas of pollution and depletion of resources. Interspersed among the pretty pictures and proclamations of progress there are, however, a few home truths. Ninety-one thousand acres of land in Britain are so polluted that they are useless without treatment, and as many more are in a "substandard condition". Attempts to solve the regional development problems in Britain "have met with limited success, but it would be idle to pretend that the answer has yet been found". Vehicle exhausts, the report says, are still a problem, Britain still has 2,000 miles of badly polluted rivers, and the discharge of 200,000 tonnes of polluting chemicals and heavy metals from industry into the ambient 